\title{
Study on the development of nonferrous metal futures market
}

\author{
Qiaozhen $\mathrm{Hu}$ \\ International Business School \\ Yunnan University of Finance and Economics \\ Kunming, China \\ 291339734@qq.com
}

Sun Meng*

International Business School

\author{
55658741@qq.com \\ University of Finance and Economics \\ Kunming, China \\ Wei Zhou \\ School of Finance \\ University of Finance and Economics \\ Kunming, China \\ zw453@163.com
}

\begin{abstract}
Since the introduction of the first commodity futures standard contract - Super aluminum futures contract in 1991, the metal futures market has developed for nearly twenty-five years.Although China's metal futures market overall development time is not long, but the development rate of the world attention, has a higher degree of market standardization, in the international metal futures market, the role and impact of increasingly prominent.The price of nonferrous metals futures has become an important benchmark price of the nonferrous metals industry in China, and has a great influence on the international market.
\end{abstract}

Keywords-nonferrous metals futures market; emerge; development

\section{INTRODUCTION}

\section{A. Non ferrous metals futures price change law related literature}

Clinton Watkins, Michael Mc Aleerto Aluminum Alloy, aluminum, copper, lead, nickel, tin, zinc 3 month futures contract data as the research object, using the risk premium hypothesis and cost model, the empirical research shows that if the spot price, futures price, interest rate and stock price variable contains a stochastic trend, you can estimate the long-term version of the general model in association within the framework of the whole [1]. Kasman A, et al. on the London metal exchange fluid and the five most important nonferrous metals (copper, aluminum, contract lead, nickel and zinc) as the research object, using multivariate heterogeneous autoregressive (HAR) model of empirical research indicates that other industrial metals volatility series seems to contain useful information for future incremental price fluctuations in the long term, the most obvious the volatility spillover [2]. Yue Y, et al.In order to Chinese nonferrous metal futures market of copper and aluminum futures as the research object, the relationship between the research, return volatility and trading activity results show that when the frequent transactions, revenue volatility increases, and when the public interest is increased, the decline in the volatility of the return [3].

\section{B. Literature on price trends forecasting}

Breedon F, Holland A Musing the 1995 second quarter data as the research object, evaluation of London (LIFFE) and Frankfurt (DTB) the relative market liquidity and price discovery, research found that this conflict is mainly a result of using price data, using the transaction price and price data (once per minute), found in the variable transaction cost two on the market (i.e. the difference) is similar [4]. China Zhong W R H, J in the Shanghai Copper Futures Exchange copper as the research object, determine whether the copper and aluminum futures price is the price discovery function, the results show that the copper futures price and the spot price has a feedback effect, the spot market price discovery leading market; on aluminum, there is only from the spot to the causal relationship between the spot market the [5]. Clinton Watkins, Michael Mc Aleer through the analysis of Aluminum Alloy, aluminum, copper, lead, nickel, tin, zinc 3 month futures contract data, the risk premium hypothesis and the cost of the standard model of the theoretical model, the results of the study show that, if the spot price, futures price, interest rate and stock price variables including stochastic trend, can estimate the long-term version of general model in a cointegration framework [6]. Rossen Athrough the study of dynamic monthly metal prices in the past 100 years, the statistical analysis method of CO movement, the price cycle and the long-term trend, and the results were compared with the results in the literature, the results show that some results in the literature is specific for non-ferrous metals and precious metals, not necessarily transfer to other metals such as steel alloy, metal electrical, light metal, steel or iron ore [7].

\section{Cross influence and risk conduction of different markets}

Christiansen Cof the United States and the European bond market volatility spillover volatility spillover, using GARCH model into the European bond market, strong statistical evidence of the United States and the European bond market overall volatility spillover was found [8]. Asgharian and Nossmartaking American and European markets as the research object, based on the extended stochastic volatility model with jumps, the risk contagion from European and 
American markets to European capital markets is studied [9].Yarovaya, et al. to ten mature financial markets in Asia, the Americas, Europe and Africa, and eleven in the development of the financial market as the research object, from 2005 to 2014, the stock index and stock index futures data, cross price fluctuations of intra and inter regional research, believes that the effect of cross regional impact than between regions is more significant [10].

\section{Research on cross influence and risk conduction of the same market}

Shyy, et al.in the Tokyo stock exchange and the Singapore International Monetary Exchange as the research object, use the Granger method to test the causal relationship between the two leading Japanese government bond futures market lag relationship, and that there is a bi-directional leading relationship between [11]. Duan and Yehconstructed a stochastic volatility jump model, and with the Chicago Board Options Exchange as the object of study, empirical research on VIX index calculation of volatility and realized volatility differences, results show that the jump factor has great influence on the fluctuation of [12]. Gannon in the Australian stock market stock price and the stock index futures price as the research object, based on GARCH model is proposed market volatility model, combined with the United States S\&P500 stock index futures data, verify the synchronous transmission and overnight contagion effect between the two [13]. Baum andZerilliwith high frequency trading day data from October 2001 to December 2012 national crude oil futures market as the research object, the cross effect of the crude oil market and crude oil futures prices in the crude oil market conduction spillover effect between, and found a jump on the accuracy of the analysis can increase the spillover effect on the price earnings conduction [14].

\section{THE EMERGENCE OF NONFERrous Metal Futures}

After the reform and opening up, the market mechanism and market system have been gradually formed with the gradual transformation of the planned economy into the market economy[15]. According to the scope of market pricing products continue to expand, prices fluctuate sharply, production and circulation are not compatible.In order to seek an effective way to solve this problem, the CPC Central Committee and the State Council leaders have made important instructions, decided to study foreign futures system , on the experience of exchanging economic development with foreign countries1, especially the Western developed countries how to use the market mechanism to rational allocation of resources. In March 25, 1988, when Premier Li Peng made the "government work report" at the first meeting of the Seventh National People's Congress, he pointed out: "We should accelerate the reform of the commercial system, actively develop various types of wholesale trade markets, and explore futures trading. "Since then, China has established a new topic for the research of the futures wholesale market.

The futures market research group after the study, believes that China should vigorously develop secure forward contracts under the conditions at that time.Regulating forward contracts with futures mechanism, starting with reforming wholesale market, combining with establishing wholesale market and rectifying market order, establishing a futures market with strict regulations and convenient trading.

After repeated arguments, decided to start with agricultural products pilot[16]. In 1990, the Zhengzhou food wholesale market (formerly known as the Zhengzhou Mercantile Exchange) was established and began trading in forward contracts for agricultural products.

Non-ferrous metal futures market is also produced in this context[17].China is an important non-ferrous metal trading nation, and some large import and export companies took part in futures trading in the international market as early as the beginning of $80 \mathrm{~s}$. They invited futures experts from abroad to teach futures theory and futures trading practice, which led to the establishment of non-ferrous metal futures market by the relevant departments.

Under the guidance of the State Administration for Restructuring Commission, the State Council Development Research Center and the State Administration for Industry and commerce, under the leadership of the people's Government of Shenzhen municipality, The Shenzhen nonferrous metals exchange was established by the China Nonferrous Metals Industry Corporation subordinate nonferrous Shenzhen joint company and colored supply and marketing transportation company and other units joint investment. The non-ferrous metal exchange was formally established in June 30, 1991 and began a forward transaction of copper, aluminium, lead, zinc, tin and nickel, six basic metals. Marking the formation of China's non-ferrous metal futures market prototype.

After the Shenzhen nonferrous metals exchange was set up for half a year, the former department and Shanghai Municipal People's Government jointly submitted to the State Council "request for instructions on trial in Shanghai Nonferrous Metals Exchange", Stating the necessity, the pilot exchange basic conditions, basic ideas and construction progress[18]. Approved by the State Council, the Shanghai Metal Exchange opened in May 28, 1992. The listed varieties are also the 6 basic metals of copper, aluminum, lead, zinc, tin and nickel. They begin with medium and long term contracts[19]. From March 1993 to November 1993, the exchange launched a standard contract for copper, aluminum, lead, zinc, tin and nickel futures, and started the futures transaction of 6 basic metal varieties[20].

\section{The Development Course of Nonferrous Metals FUTURES}

The first stage (1992 - 1998) : This stage is marked by the establishment of the Shenzhen and Shanghai Nonferrous Metals Exchange in 1992,solving three big practical problems of the prices of real economy, customers, credit. At this stage, production-oriented enterprises more delivery. In 1992, Shenzhen Nonferrous Metals Exchange launched the first Chinese aluminum futures standard contract, then the Shanghai Metal Exchange copper futures launched a standard contract, finally, a new situation of "South North aluminum copper" was formated. 
The second stage (1998 - 2004): At this stage, China's futures market supervision system has undergone tremendous changes,and the effective regulatory system began to establish, and the market gradually standardized. China Futures Association (2000) and the Nonferrous Metals Industry Association (2001) has been established, marking the two industries gradually toward the fittest market development stageofself-management,self-disciplinemanagement, survival. At the same time, production-oriented enterprises reduce to delivery, foreign trade enterprises increased delivery.

The third stage (2004 to present): At this stage, the delivery of non-ferrous metal of production and trade oriented enterprises have substantially reduced,while the financing delivery increasing. Nonferrous metals enterprises generally began to effectively use two futures markets both at home and abroad.The price system of non-ferrous metal futures market runs through the whole industry chain, which greatly improves the efficiency of resource allocation.In 2008 after the financial crisis, the futures market aimed to reach the stages of development of the real economy, and seized the opportunity to carry out a series of supporting services, including brand registration, copper bonded warehouse delivery pilot at the Shanghai futures exchange, in order to support the Chinese enterprises "going out" strategy. At this stage, the international authority of Chinese nonferrous metal futures market gradually increased, with copper as an example, from the former London copper "shadow price"to now on an equal footing to London copper. The international influence of the price of nonferrous metals in Shanghai is increasing day by day, which laid a solid foundation for our country's right to speak in the global market.

\section{INTRODUCTION OF NONFERROUS METALS FUTURES MARKET AT HOME AND ABROAD}

After the development of agricultural commodities futures, the metal futures market began to come into being, and also gained great development.In the 60-70 century, the metal futures market began in the UK in twentieth Century, then followed by a number of exchanges. With the rapid development of the futures market in the United States, the European futures market represented by the London Metal Exchange(LME) began to accelerate and develop.

By the middle of the nineteenth Century, Britain had become the world's largest producer of metal, tin and copper.Under the conditions at that time, as a result of road transportation and other issues, the transaction risk was great, British businessmen and consumers adopted the booking price method to face the price risk of copper and tin, the method was that before the goods have arrived, they will sign the contract for future arrival, so as to ensure that a large quantity of goods can be shipped when they are shipped and when the quantity is limited, the price will not rise.

In 1876, the London Metal Exchange was established, mainly engaged in copper and tin futures trading. After that, the London Metal Exchange traded rapidly, especially in the form of trading circles, and became the most important trading mode of the London Metal Exchange at that time and even now.In 1920, two metals of $\mathrm{Zn}$ and $\mathrm{Pb}$ were officially traded within the trading circle, and the trading of pig iron was terminated.For the next few decades, the metal exchanges in London had only four metals: copper, tin, lead and zinc. The London Metal Exchange has been booming since its establishment.With the continuous expansion of the stock exchange, trading varieties have been further increased, the scale of the transaction has been expanding, and the market mechanism has been improved day by day, which making it the world's largest international metal products exchange. Metal futures at the London Metal Exchange have grown from the first two varieties of copper and tin to seven futures, namely copper, aluminium, lead, zinc, nickel, tin and aluminium alloys. The London Metal Exchange has formed an international metal trading market represented by these seven metals.

The advent of metal futures in the United States was later than in Britain. At the end of the 19 world and the beginning of the twentieth Century, the American economy shifted from agriculture to the establishment of a modern industrial system. The types of futures contracts gradually expanded from traditional agricultural products to metals and energy commodities. The New York COMEX, established in 1933, is a merger of leather, raw silk, rubber and metal exchanges. The commodities of the New York mercantile exchange are gold, silver, copper and aluminum.

At present, the world's major non-ferrous metals futures trading is concentrated in the London Metal Exchange, the New York COMEX and the Tokyo industrial exchange. In particular, the LME futures contract price is recognized by the world as the pricing standard for non-ferrous metals trading. China's Shanghai Futures Exchange copper futures trading is growing rapidly in recent years, the copper single species turnover has more than the New York Mercantile Exchange, ranking second in the world.At present, the Shanghai Futures Exchange, non-ferrous metal futures trading varieties are copper, aluminum, zinc, gold. At the same time, in 2009, the new varieties of steel futures, rebar and wire were added.

\section{CONCLUSION}

This paper introduces the general situation of the Shanghai futures exchange market, including the current listing of varieties, in the international metal futures market on the status of the status quo, from 1990 Zhengzhou grain wholesale market officially introduced the futures trading mechanism began to introduce the development process of China's futures market, introduced the copper and aluminum, zinc and other non-ferrous metal products and the corresponding futures in the case of the Shanghai futures exchange.

\section{ACKNOWLEDGEMENT}

This work was supported by the Natural Science Foundation of China (No. 71561026); Science Foundation and Major Project of Educational Committee of Yunnan Province (Grant No. 2014Z100), and Philosophy and Social Science Foundation of Yunnan Province (Grant No. YB2015087). 


\section{REFERENCE}

[1] C. Watkins, and M. McAleer, "Pricing of non-ferrous metals futures on the London Metal Exchange," vol. 16, Cooking Knowledge, 2003, pp. 853-880.

[2] A. Kasman, S. Kasman, and E. Torun, "Dual long memory property in returns and volatility: Evidence from the CEE countries' stock markets," vol. 10, Emerging Markets Review, 2009, pp. 122-139.

[3] Y. Yue, D. Liu, and S. Xu, "Relationship between returns volatility and trading activity: Evidence from Chinese non-ferrous metals futures market," vol. 5, 2013, pp. 110-117.

[4] F. Breedon, and A.M. Holland, "Electronic versus open outcry markets: The case of the Bund futures contract,"Ssrn Electronic Journal, 1998.

[5] R.H. Hua, and W.J. Zhong, "An empirical analysis on price discovery in our futures markets," vol. 5, Nankai Business Review, 2002, pp. 57-61.

[6] W. Clinton, and M. Michael, "Pricing of non-ferrous metals futures on the London Metal Exchange," vol. 16, Applied Financial Economics, 2006, pp. 853-880.

[7] A. Rossen, "What are metal prices like? Co-movement, price cycles and long-run trends," vol. 45, Hwwi Research Papers, 2015, pp. 255-276.

[8] C. Christiansen, "Volatility-Spillover Effects in European Bond Markets," vol. 13, European Financial Management, 2007, pp. 923-948.

[9] H. Asgharian, and M. Nossman. "Risk contagion among international stock markets," vol. 30, Journal of International Money and Finance, 2011, pp. 22-38.

[10] L. Yarovaya, J. Brzeszczyński, and C.K.M. Lau, "Intra-and inter-regional return and volatility spillovers across emerging and developed markets: Evidence from stock indices and stock index futures," vol. 43, International Review of Financial Analysis, 2016, pp. 96-114.
[11] G. Shyy, and B. Butcher, "Price equilibrium and transmission in a controlled economy: a case study of the metal exchange in China," vol. 14, Journal of Futures Markets, 1994, pp. 877-890.

[12] J.C. Duan, and C.Y. Yeh, "Jump and Volatility Risk Premiums Implied by VIX," vol. 34, Journal of Economic Dynamics and Control, 2010, pp. 2232-2244.

[13] G.L. Gannon, "Simultaneous volatility transmission and spillover effects," vol. 13, Review of Pacific Basin financial markets and policies, 2010, pp. 127-156.

[14] C.F. Baum, and P. Zerilli, "Jumps and stochastic volatility in crude oil futures prices using conditional moments of integrated volatility," vol. 53, Energy economics, 2014, pp. 175-181.

[15] W. Zhou, and J.M. He, "Generalized GM $(1,1)$ model and its application in forecasting of fuel production," vol. 37, Applied Mathematical Modelling, 2013, pp. 6234-6243.

[16] W. Zhou, and D.M. Zhang, "An improved metabolism grey model for predicting small samples with a singular datum and its application to sulfur dioxide emissions in China," vol. 53, Discrete Dynamics in Nature and Society, 2016, pp. 1-12.

[17] W. Zhou, B.Q. Ding, and Y. Zhang, "The improved grey model by fusing exponential buffer operator and its application," Journal of Intelligent and Fuzzy Systems, 2017. (On line)

[18] W. Zhou, and Z. Xu, "Generalized asymmetric linguistic term set and its application to qualitative decision making involving risk appetites," vol. 254, European Journal of Operational Research, 2016, pp. 610-621.

[19] W. Zhou, "Dynamic and asymmetric contagion reactions of financial markets during the last subprime crisis," Computational Economics, 2016.

[20] W. Zhou, and J. He, "Intuitionistic fuzzy geometric Bonferroni means and their application in multicriteria decision making," vol. 27, International Journal of Intelligent Systems, 2012, pp. 995-101. 